\title{
SOSIO ANTROPOLOGI TERHADAP GIZI DAN KESEHATAN
}

\section{Syamsurya Junita}

\section{(70200121105)}

\begin{abstract}
Program Studi Kesehatan Masyarakat, Fakultas Kedokteran dan Ilmu Kesehatan
Universitas Islam Negeri Alauddin Makassar
\end{abstract}

\begin{abstract}
ABSTRAK
Sosio Antropologi adalah ilmu yang mempelajari hubungan antara individu dengan masyarakat dari sudut pandang keanekaragaman fisik dan kebudayaannya. Semua kebudayaan atau kebiasaan yang dilakukan masyarakat seperti proses memperoleh makanan yang memiliki berbagai kandungan gizi, perilaku hidup bersih dan sehat memiliki keragaman disetiap wilayah masingmasing. Tujuan penelitian untuk menegetahui pengaruh sosio antropologi terhadap gizi.
\end{abstract}

Kata Kunci: social budaya, kesehatan, makanan, gizi

\section{Pendahuluan}

Sosio antropologi berasal dari dua kata yaitu "sosio" yang berarti interaksi antara satu individu dengan yang lainnya dan Kata antropologi merupakan dua suku kata yang mana dalam bahasa Yunani disebut dengan "Antrhopos" dan "Logos". Antropos mempunyai arti manusia dan logo adalah ilmu. secara harfiah maka antropologi mempunyai arti sebuah ilmu yang mempelajari manusia dari sudut pandang keanekaragaman fisik dan kebudayaannya.

Antropologi bertujuan untuk membangun budaya di masyarakat dengan mempelajari perilakunya, mempelajari bagaimana manusia dapat bersosial di masyarakat luas termasuk di dalam suku bangsa maupun budaya, pemaduan 
integratif antara biologi dan sosio-budaya dalam kehidupan manusia atau masyarakat. Antropologi merupakan ciri-ciri dari suatu masalah bagaimana kebudayaan masyarakat berubah sepanjang waktu termasuk dari segi makanan, dimana awalnya memperoleh makanan dari hasil pertanian secara langsung dan tentunya mengandung karbohidrat, protein, dan lain sebagainya. sedangkan, pada masa sekarang sudah bisa memperoleh makanan impor secara instan yang mengandung zat pengawet, zat pewarna, dan lain sebagainya. Makanan yang dikonsumsi merupakan penentu gizi kesehatan bagi tubuh kita. masalah gizi terjadi di banyak tempat di berbagai daerah di Indonesia, hanya sebagian pihak yang memandangnya sebagai fenomena sosial. Sebagian lain masih menganggap hal ini sebagai fenomena kesehatan semata. Tidak banyak yang menyadari luasnya dimensi masalah gizi dapat meliputi masalah lingkungan dan ketersediaan pangan, pola asuh dan pendidikan, kondisi ekonomi dan budaya.

Gizi merupakan unsur terpenting bagi kesehatan tubuh, tapi kelebihan asupan gizi pada tubuh pun bisa menimbulkan gangguan pada kesehatan. Oleh karena itu, dibutuhkan pengetahuan komprehensif akan gizi dan pola hidup sehat agar asupan gizi yang masuk dalam tubuh betul-betul seimbang. Ilmu gizi membahas segala sesuatu tentang makanan dalam hubungannya dengan kesehatan tubuh yang optimal agar tidak mengalami penyakit gangguan gizi. Gaya hidup yang salah dapat memicu berbagai penyakit dan merusak konsep gizi seimbang dan menggiring untuk pola makan tidak sehat.

Berdasarkan penelitian di atas penulis tertarik untuk mengkaji lebih dalam lagi mengenai "Sosio Antropologi terhadap gizi".

\section{Pola Budaya Komunitas Terhadap Makanan}

Sosio antropologi memiliki pandangan pentingnya pendekatan budaya. Dimana kebudayaan sendiri diturunkan dari satu generasi ke generasi berikutnya dengan mengguanakan symbol, bahasa, seni, dan ritual yang dilakukan dalam bentuk kehidupan sehari-hari. Di sisi lain, latar belakang budaya memiliki pengaruh penting dalam berbagai aspek kehidupan manusia seperti kepercayaan, 
perilaku, persepsi, emosi, bahasa, agama, ritual, struktur keluarga, pola makan, pakaian, sikap terhadap penyakit, dan lain-lain. Inilah yang mempengaruhi derajat kesehatan masyarakat dan pola pelayanan kesehatan yang putus asa di masyarakat.

Pola makanan atau produk dari budaya dan perlakuan tergantung dari system sosial kemasyarakatan dan wilayahnya masing-masing. Hal ini berpengaruh adanya beranekaragam makanan dari semua komunitas. Contohnya sagu, banyak daerah yang menggunakan sagu berbeda-beda ada yang membuat kapurung, cendol dan lain sebagainya.

Faktor budaya memengaruhi siapa yang mendapat asupan makanan, jenis makanan yang didapat dan banyaknya. Sangat mungkin karena kondisi budaya dan kebiasaan ini seseorang mendapatkan asupan makanan lebih sedikit dari yang sebenarnya ia butuhkan. Memahami keterkaitan antara kebiasaan makan, pola makan, sistem keluarga dan pengolahan makanan dapat membantu tenaga kesehatan, penyusun kebijakan dan program kesehatan dalam memahami kondisi gizi dan kesehatan masyarakat Indonesia secara lebih menyeluruh. Dengan demikian penyusunan strategi kebijakan dan program-program upaya peningkatan status gizi masyarakat dapat lebih tepat guna dan sasaran.

\section{Sistem Budaya Terhadap Makanan}

1. Memberikan nilai yang beda terhadap makanan

Budaya makan masyarakat juga bergantung pada selera, citarasa, kenikmatan dan daya terima akan suatu makanan. Di masyarakat, setiap kelompok mempunyai suatu pola tersendiri dalam memperoleh, menggunakan, dan menilai makanan yang akan merupakan ciri kebudayaan dari kelompok masing-masing. Umumnya masyarakat memberikan definisi tertentu tentang arti makanan seperti: ada jenis makanan untuk dijual dan lainnya untuk dimakan di rumah, ada jenis makanan untuk orang kaya dan ada yang untuk orang miskin, ada yang 
untuk pesta, untuk wanita, anak-anak, orang tua dan orang sakit, ada jenis makanan yang tidak diperbolehkan untuk orang-orang tertentu.

2. Factor social ekonomi mempengaruhi pola makan

Orang yang memiliki ekonomi kelas atas lebih memilih makanan impor dan instan sedangkan orang yang memiliki ekonomi kelas menengah ke bawah berpikir bahwa dia hanya bisa mengonsumsi makanan local yang berasal dari sumbenrnya langsung dan tentunya mengandung gizi yang banyak karena murni dari asalnya.

3. Cara mengonsumsi makanan di dalam keluarga

Contohnya, ayah lebih mementingkan uangnya untuk membeli rokok daripada untuk membeli susu anaknya. Berdasarkan kasus tersebut dapat dinyatakan bahwa prioritas makan yaitu menjadikan kebutuhan lain yang lebih diutamakan daripada kebutuhan makanan terutama asupan gizi dalam keluarga.

4. Mengistimewakan tamu

Dalam hal ini menempatkan tamu menjadi prioritas utama untuk mendapatkan makanan banyak protein dan kalori dengan alasan gengsi.

\section{Masalah Budaya Terhadap Gizi}

1. Di Indonesia, sebagian besar masyarakat menganut sistem patriarki. Dalam sistem patriarki, garis keturunan diambil dari seorang Ayah (laki-laki), status sosial laki-laki lebih tinggi daripada perempuan. Konsekuensinya, ayah lebih sering diutamakan memakan makanan yang telah disajikan oleh Ibu. Sesederhana ayah lah yang paling sering mendapatkan jatah makanan lebih dulu di meja makan. Bahkan, beberapa daerah di Indonesia mengharuskan pemisahan antara makanan yang harus disajikan untuk Ayah dan anggota keluarga yang lain. Kondisi budaya seperti ini turut berkontribusi pada kondisi gizi anak dan ibu hamil di dalam keluarga karena semua sistem keluarga patriarki berhubungan erat dengan ketidaksetaraan gender. 
2. Permasalahan gizi harus diperhatikan sejak masih dalam kandungan. Daerah perkotaan memiliki tingkat kesibukan yang tinggi sehingga kurangnya asupan air susu ibu kepada bayinya dan solusinya susu formula.. Gangguan pertumbuhan dalam kandungan dapat menyebabkan berat badan lahir rendah yang berisiko mengalami stunting. Stunting adalah kondisi dimana balita memiliki panjang atau tinggi badan yang kurang jika di bandingkan dengan anak seusianya. ASI eksklusif dapat mempengaruhi kejadian stunting karena jika bayi yang belum cukup umur 6 bulan sudah diberi makanan selain ASI akan menyebabkan usus bayi tidak mampu mencerna makanan dan bayi akan mudah terkena penyakit karena kurangya asupan. Sehingga balita yang sering menderita penyakit infeksi akan menyebabkan pertumubuhannya terhambat dan tidak dapat mencapai pertumbuhan yang optimal.

\section{Mengatasi Masalah Budaya dan Makanan Terhadap Budaya dan Makanan}

1. Secara cermat untuk memberdayakan kecerdasan local mengenai pengetahuan informasi makanan yang mengandung gizi

2. Perbaiki gizi keluarga

3. Perbaikan budaya masyarakat pengaruh utama yaitu kesetaraan gender

4. Penyuluhan terhadap gizi

5. Melakukan pendekatan sesuai kebiasaan masyarakat tentang pandangan mereka mengenai gizi

6. Melakukan kajian dan riset pengaruh terhadap makanan dan implementasi terhadap masyarakat 


\section{DAFTAR PUSTAKA}

Budaya Makan Prioritas Makan. (n.d.). Retrieved December 8, 2021, from https://textid.123dok.com/document/wyeel1g4y-budaya-makan-prioritas-makan.html

Ibrahim, I. A., Alam, S., Adha, A. S., Jayadi, Y. I., \& Fadlan, M. (2021). Hubungan Sosial Budaya Dengan Kejadian Stunting Pada Balita Usia 24-59 Bulan Di Desa BoneBone Kecamatan Baraka Kabupaten Enrekang Tahun 2020. Al GIZZAI: PUBLIC HEALTH NUTRITION JOURNAL, 1(1), 16-26. https://doi.org/10.24252/algizzai.v1i1.19079

MASALAH GIZI DALAM ANALISIS SOSIAL BUDAYA Pencerah Nusantara. (n.d.). Retrieved December 8, 2021, from https://pencerahnusantara.org/news/masalah-gizidalam-analisis-sosial-budaya

Satrianegara, M. F., Juhannis, H., Lagu, Abd. M. H. R., Habibi, Sukfitrianty, \& Alam, S. (2021). Cultural traditional and special rituals related to the health in Bugis Ethnics Indonesia. Gaceta Sanitaria, 35, S56-S58.

https://doi.org/10.1016/j.gaceta.2020.12.016

SOSIO ANTROPOLOGI KESEHATAN. - PDF Free Download. (n.d.). Retrieved December 8, 2021, from https://docplayer.info/72830022-Sosio-antropologi-kesehatan.html 